Вадим Шемчук,

кандидат педагогічних наук, Національний університет оборони України імені Івана Черняховського ORCID ID 0000-0001-8873-0443

Олександр Хацаюк, магістр, заслужений тренер України Харківський національний університет внутрішніх справ

ORCID ID 0000-0002-4166-9099

Володимир Соколовський, кандидат педагогічних наук, Національна академія Національної гвардії України

ORCID ID 0000-0002-3930-4541

Артем Ковтуненко,

Національна академія Національної гвардії України

ORCID ID 0000-0002-3062-2121

Олександр Корніснко,

Національний університет оборони України імені Івана Черняховського

ORCID ID 0000-0002-5433-8184

Юрій Муштатов,

Національний університет оборони України імені Івана Черняховського

ORCID ID 0000-0002-7831-7345

DOI: $10.33099 / 2617-1775 / 2021-01 / 360-380$

\title{
ФОРМУВАННЯ ПРОФЕСІЙНИХ КОМПЕТЕНТНОСТЕЙ МАЙБУТНІХ ОФІЦЕРІВ ДО ДІЙ В УМОВАХ РАДІАЦІЙНӦ̈, ХІМІЧНОЇ ТА БІОЛОГІЧНОЇ НЕБЕЗПЕКИ
}

Розглянуто актуальну проблему формування прикладних професійних компетентностей майбутніх офріцерів (на прикладі курсантів груп спеціального призначення Національної академії Національної гвардії України) до дій в умовах радіаційної, хімічної та біологічної небезпеки. Підсумовуючи результати моніторингу науково-методичної та спеціальної літератури (інтернет-ресурсів), членами науково-дослідної групи сконструйовано та апробовано змістово-функиіональну модель, яка забезпечує формування готовності майбутніх офіцерів (курсантів груп спеціального призначення Національної академії Національної гвардї Украӥни) до дій в екстремальних умовах (радіаційної, хімічної та біологічної небезпеки) із використанням засобів спечіальної фізичної підготовки.

Відповідно до результатів емпіричного дослідження, членами науково-дослідної групи встановлено, щзо результати, отримані наприкінці педагогічного експерименту $y$ досліджуваних групах, зросли відносно вихідних даних, $i$ иі відмінності переважно $\epsilon$ достовірні (ЕГ, $p \leq 0,05)$. Крім иього, наприкінці дослідження, членами науково-дослідної групи встановлено, щцо рівень витривалості, швидкості, сили та спритності у досліджуваних курсантів ЕГ підвищився, на відміну від курсантів КГ про щзо свідчать результати заліку з навчальної дисципліни «Спеціальна фізична підготовки» (7 семестр 2020/2021 навчальний рік, у досліджуваних ЕГ - середній рівень спеціальної фізичної підготовленості складає 4,9 бали, у той час, як у курсантів КГ зазначений показник знаходиться в межах 4,6 бали). Варто зауважити, щчо також підвищилися якісні показники відпрацювання нормативів з бойової та спеціальної підготовки військовослужбовиів НГУ, так у курсантів ЕГ середній бал за виконання тренувальних завдань складає 4,7 бали, у той час, як у курсантів КГ зазначений показник сягає відмітки 4,2 бали. 
Членами науково-дослідної групи встановлено високу ефективність засобів спеиіальної фізичної підготовки, що сприяло ефективному формуванню прикладних професійних компетентностей у досліджуваних курсантів ЕГ. Зазначена педагогічна модель може використовуватися в системі професійної освіти офіцерів інших інституцій сектору безпеки і оборони України із урахуванням нормативно-правової бази, щуо сприятиме більш стійкому та якісному формуванню прикладних професійних компетентностей, які необхідні для виконання завдань в умовах радіаційної, хімічної та біологічної небезпеки (екстремальних умовах).

Ключові слова: біологічний захист, компетентнісний підхід, курсанти, радіачійний захист, педагогічна модель, професійна освіта, професійна підготовка, спеціальна фізична підготовка, хімічний захист

Постановка проблеми. Сучасний розвиток освітнього простору України характеризується процесами європейської інтеграції, які впливають на всі сфери життя суспільства, у тому числі й систему професійної освіти майбутніх офіцерів різних інституцій сектору безпеки i оборони (СБО) України. Основними орієнтирами модернізації системи національної гвардії України, Збройних Сил України та інших інституцій СБО є перехід на світові стандарти (стандарти НАТО), що потребує відповідних змін в освітньому процесі підготовки майбутніх офіцерів різних спеціальностей (галузей знань та відповідної спеціалізації).

Варто зауважити, що основними завданнями трансформації інституцій СБО України до світових стандартів є створення умов для всебічного розвитку конкурентоспроможного, компетентного військового фахівця (тактичного, оперативно-тактичного рівнів), здатного до професійного самовдосконалення упродовж тривалої військової служби. Компетентність випускника ВВНЗ $є$ індикатором його готовності до військово-професійної діяльності та активної ролі у повсякденній діяльності свого підрозділу (військової частини, тощо).

Актуальність дослідження зумовлена наявним станом вищої військової освіти як соціального інституту, який забезпечує професійну успішність індивіда (військовослужбовця) та його успішну адаптацію до вимог сьогодення (вимог військово-професійної діяльності). Варто також зауважити, що компетентнісний підхід на сьогодні $\epsilon$ одним iз пріоритетних напрямів удосконалення системи вищої військової освіти в Україні, який забезпечує реалізацію концепції військового навчання, виховання, розвитку і передбачає підготовку компетентних військових фахівців, які вільно володіють професією та орієнтуються в суміжних галузях діяльності, готових до постійного професійного зростання (кар'єрних домагань), соціальної та професійної мобільності.

Впровадженню компетентнісного підходу в освітній процес представників СБО України присвячені наукові праці: А. Балендара, О. Богданюка, Ю. Дем'янюка, С. Нехаєнка, В. Оліферука, П. Рибалка, А. Турчинова, В. Шевченка, С. Шварова, В. Ягупова (та інших провідних учених і практиків). Важливим $\epsilon$ й той факт, що виконання завдань за призначенням військовослужбовцями різних інституцій СБО України може відбуватися в умовах радіаційної, хімічної та біологічної небезпеки (екстремальних умовах), що потребує від даних представників СБО України відповідної професійної 
підготовленості. Крім цього, виконання завдань за призначенням у зазначених вище умовах потребує високого рівня фізичного розвитку військовослужбовців різних категорій та вікових груп, який досягається засобами спеціальної фізичної підготовки і $є$ актуальним та практичним напрямом наукової розвідки.

Використання актуальних педагогічних технологій (методик) в системі професійної освіти майбутніх офіцерів різних інституцій СБО України забезпечує формування у них прикладних професійних компетентностей і $\epsilon$ важливим практичним завданням.

Дослідження виконано відповідно до планів науково-дослідної роботи i дослідно-конструкторських робіт: науково-дослідного відділу розвитку фізичного виховання, спеціальної фізичної підготовки і спорту науководослідного центру проблем фізичного виховання, спеціальної фізичної підготовки і спорту навчально-наукового інституту фізичної культури та спортивно-оздоровчих технологій Національного університету оборони України імені Івана Черняховського; кафедри фізичної підготовки та спорту Національної академії Національної гвардії України (2019-2021 років).

Аналіз останніх досліджень і публікацій. Аналіз науково-методичної літератури та інтернет-джерел у напрямі формування професійних компетентностей майбутніх офіцерів, представників інституцій сектору безпеки і оборони України в системі їх професійної освіти, дозволив визначити ряд наукових праць: О. Бойка [1], Л. Боровик [2], О. Хацаюка [3], М. Саморока, В. Халепа, Н. Височіної, О. Хацаюка, Р. Іванішина [4], В. Шемчука, А. Турчинова, В. Климовича, Є. Гончарова, Р. Тріщуна [5], В. Шемчука, Н. Вербина, О. Нестерова, М. Власенка, С. Малахова [6] та ін.: П. Дармограя, О. Діденка, Л. Маслака, А. Турчинова, А. Шевченка. Окремі положення, наукові підходи, методики (технології) зазначених вище авторів доцільно модернізувати та використати під час конструювання сучасної моделі формування професійних компетентностей майбутніх офіцерів досліджуваної категорії.

Цікавими за своїм змістом та структурою (науковою новизною) є роботи: О. Войтеха [7], О. Флоріна, С. Стародубцева, О. Шаповала [8], І. Приходька [9], О. Хацаюка, О. Єлісєєвої, В. Жукова, В. Клименка, Ю. Бережного [10] та інших учених: Г. Дробахи, В. Колянди, В. Молдавчука, С. Решетника, Р. Троцького, у яких розкриваються особливості організації системи бойової та спеціальної підготовки військовослужбовців Національної гвардії України (представників різних інституцій СБО України). Варто зауважити, що сучасні погляди та концепції на систему професійної підготовки військовослужбовців досліджуваних категорій (представників інституцій СБО України можуть бути використані під час розроблення педагогічних умов майбутньої педагогічної моделі формування прикладних професійних компетентностей курсантів різнопрофільних ВВНЗ, військових навчальних підрозділів ЗВО України.

В наукових працях: I. Ісмаілова, А. Ісмаілова [11], С. Трегубенка, О. Гутченка, I. Тіхонова [12], С. Лазебника, С. Поплавця [13], Л. Кузьменка [14], О. Лещенка [15], О. Іващенка [16], та інших провідних учених і практиків: В. Антіпова, О. Кірєєва, М. Корчагіна, В. Сердюка висвітлені та розкриті актуальні питання забезпечення готовності майбутніх 
офіцерів різних інституцій СБО України до дій в умовах радіаційної, хімічної та біологічної небезпеки. Зазначені у роботах провідних фахівців радіаційного, хімічного та біологічного захисту (надалі РХБЗ) методи (форми) удосконалення професійної підготовленості військовослужбовців різних груп та вікових категорій доцільно модернізувати та адаптувати у систему бойової та спеціальної підготовки військовослужбовців Національної гвардії України (НГУ).

Крім цього, у нормативно-правових документах [17-20] та спеціальній науково-методичній літературі [21-22] визначаються пріоритетні навчальні дисципліни (напрями), які забезпечують формування прикладних професійних компетентностей майбутніх офіцерів (різних інституцій СБО України) до дій в умовах радіаційної, хімічної та біологічної небезпеки.

Враховуючи результати напрацювань зазначених вище науковців $\mathrm{i}$ практиків та вимоги нормативно-правових документів, актуальним $\epsilon$ удосконалення системи професійної освіти майбутніх офіцерів НГУ (й інших інституцій СБО України) у напрямі формування їх готовності до дій в умовах радіаційної, хімічної та біологічної небезпеки (екстремальних умовах). У свою чергу, зазначені умови підкреслюють практичну складову розвитку та удосконалення спеціальної фізичної підготовленості військовослужбовців НГУ (представників СБО України), що забезпечить надійне та ефективне виконання ними завдань за призначенням.

В роботах: О. Моргунова, О. Ярещенка, О. Хацаюка [23], Б. Максимчука, Є. Терехова, О. Хацаюка [24], О. Войтеха, К. Войтех [25], С. Горбачевського [26], А. Коноха, В. Шемчука, О. Конох, I. Будзи, I. Бужини [27] та інших науковців: О. Антонової, Ю. Дем'янюка, А. Машталера, О. Лемешка, О. Марченка - розкриваються методологічні особливості розроблення педагогічних моделей (технологій), які спрямовані на формування професійних компетентностей у майбутніх офіцерів (представників СБО України). Окремі структурні, прикладні та змістово-функціональні елементи й блоки педагогічних моделей запропонованих зазначеними вище вченими, можуть бути використані під час конструювання сучасної педагогічної моделі, яка сприятиме більш функціональному та ефективному формуванню прикладних професійних компетентностей у курсантів різних ВВНЗ (майбутніх офіцерів різних інституцій СБО України).

Мета дослідження - розроблення та апробація педагогічної моделі формування прикладних професійних компетентностей майбутніх офіцерів до дій в умовах радіаційної, хімічної та біологічної небезпеки із акцентованим використанням засобів спеціальної фізичної підготовки.

Для досягнення мети дослідження планувалося вирішити наступні завдання:

- здійснити аналіз науково-методичної літератури та інтернет-джерел у напрямі формування професійних компетентностей майбутніх офіцерів різних структур СБО України в системі їх професійної освіти;

- визначити особливості організації системи бойової та спеціальної підготовки військовослужбовців Національної гвардії України; 
- проаналізувати спеціальну науково-методичну літературу у напрямі забезпечення готовності майбутніх офіцерів різних інституцій СБО України до дій в умовах радіаційної, хімічної та біологічної небезпеки;

- визначити пріоритетні навчальні дисципліни, які забезпечують формування прикладних професійних компетентностей майбутніх офіцерів до дій в умовах радіаційної, хімічної та біологічної небезпеки;

- здійснити аналіз спеціальної наукової літератури у напрямі розроблення педагогічних моделей, спрямованих на формування прикладних професійних компетентностей у майбутніх офіцерів (представників СБО України);

- розробити та апробувати педагогічну модель формування професійних компетентностей майбутніх офіцерів, на прикладі курсантів груп спеціального призначення командно-штабного факультету Національної академії Національної гвардії України (надалі НАНГУ) до дій в умовах радіаційної, хімічної та біологічної небезпеки (надалі РХБН) із акцентованим використанням засобів спеціальної фізичної підготовки (надалі СФП).

Методи дослідження: аналітичний огляд та аналіз результатів науковометодичної, спеціальної літератури (інтернет-ресурсів), педагогічне моделювання, педагогічне спостереження, експертна оцінка, методи статистичної обробки результатів, біомеханічний аналіз, відеоаналіз, власний досвід участі в бойових дій (умовах радіаційної, хімічної та біологічної небезпеки), тощо.

Виклад основного матеріалу. Дослідження організовано упродовж трьох етапів (серпень 2019-січень 2021 р.р.). На першому етапі (червень-липень 2019 р.) було створено науково-дослідну групу до складу якої увійшли провідні учені та практики зазначеного напряму наукової розвідки: В.Шемчук, О. Хацаюк, В. Соколовський, А. Ковтуненко, О. Корнієнко, Ю. Муштатов. Крім цього, членами науково-дослідної групи (НДГ) було здійснено моніторинг науково-методичної та спеціальної літератури (інтернет-ресурсів) у обраному напрямі дослідження.

Упродовж другого етапу дослідження (серпень 2019 р.), відповідно до результатів моніторингу науково-методичної та спеціальної літератури (інтернет-ресурсів), а також враховуючи аналітичні звіти результатів виконання завдань за призначенням представниками різних інституцій СБО України в умовах радіаційної, хімічної та біологічної небезпеки (умовах всесвітньої пандемії спричиненої вірусом SARS-CoV-2), членами НДГ сконструйовано педагогічну модель формування прикладних професійних компетентностей майбутніх офіцерів НГУ до дій в умовах РХБН із акцентованим використанням засобів СФП (рис. 1).

Основними блоками зазначеної вище змістово-функціональної моделі $є$ : цільовий блок, блок методологічного забезпечення, діяльнісно-практичний блок, організаційно-змістовий блок та результативно-оцінний блок.

Під час третього етапу емпіричного дослідження (вересень 2019 січень 2021 років) членами НДГ здійснено апробацію змістово-функціональної моделі (рис. 1) формування прикладних професійних компетентностей майбутніх офіцерів (курсантів НАНГУ, n=24 чол.) до дій в умовах радіаційної, 
хімічної та біологічної небезпеки із акцентованим використанням засобів СФП. Варто зауважити, що всі курсанти та члени НДГ дали згоду на участь в педагогічному експерименті, що засвідчено відповідним актом та відомостями. Крім цього, досліджуваних курсантів та членів НДГ було проінформовано та проінструктовано по суворому дотриманню заходів попередження травматизму, військової дисципліни під час відпрацювання основних блоків педагогічного експерименту (третього етапу дослідження).

Надалі учасників емпіричного дослідження було розподілено на репрезентативні: контрольну (КГ, $\mathrm{n}=12$ чол.) та експериментальну групи (ЕГ, $\mathrm{n}=12$ чол.). До початку педагогічного експерименту досліджувані курсанти КГ та ЕГ за рівнем сформованості професійних компетентностей до дій в умовах РХБН достовірно не відрізнялися $(p \geq 0,05)$.

3 метою формування прикладних професійних компетентностей до дій в умовах радіаційної, хімічної та біологічної небезпеки, представниками КГ під час вивчення навчальної дисципліни «Бойове забезпечення» (Змістовий модуль 2. Зброя масового ураження) [29] використовувалася загальноприйнята методика. У свою чергу, курсанти командно-штабного факультету ЕГ в освітньому процесі використовували сконструйовану нами змістовофункціональну модель (рис. 1) та відповідний план іiі практичного впровадження (табл. 1).

Розроблена нами педагогічна модель (рис. 1) використовувалася досліджуваними курсантами ЕГ двічі на тиждень упродовж третього етапу дослідження (під час практичних занять із наступних навчальних дисциплін: «Бойове забезпечення» [29], «Спеціальна фізична підготовка» [30]).

\begin{tabular}{|c|}
\hline Цільовий блок \\
\hline Мета - формування професійних компетентностей майбутніх офіцерів до \\
\hline Теоретичні концепти компетентнісного підходу у вищій військовій освіті України \\
\hline Метамета: формування професійних компетентностей майбутніх офіцерів в \\
\hline $\begin{array}{c}\text { Військово-професійний (прикладний) аспект розвитку та удосконалення } \\
\text { спеціальної фізичної підготовленості майбутніх офіцерів до дій в умовах } \\
\text { радіаційної, хімічної та біологічної небезпеки }\end{array}$ \\
\hline Блок методологічного забезпечення \\
\hline $\begin{array}{c}\text { Теоретико-методологічна складова реалізації компетентнісно-орієнтованого } \\
\text { підходу професійної освіти майбутніх офіцерів. } \\
\text { Методологічні підходи: системний, компетентнісний, діяльнісний, } \\
\text { особистісно-орієнтований }\end{array}$ \\
\hline $\begin{array}{l}\text { Принципи: послідовності, дидактичності, комплексності, варіативності, } \\
\text { інтенсифікації та систематизації знань і умінь, науковості, зв'язку теорії із практикою, } \\
\text { доступності, функціональності } \\
\text { Парадигми вищої військової освіти майбутніх офіцерів: особистісно- }\end{array}$ \\
\hline $\begin{array}{l}\text { методологічний супровід реалізації компетентнісно-орієнтованої вищої } \\
\text { військової освіти майбутніх офіцерів }\end{array}$ \\
\hline
\end{tabular}




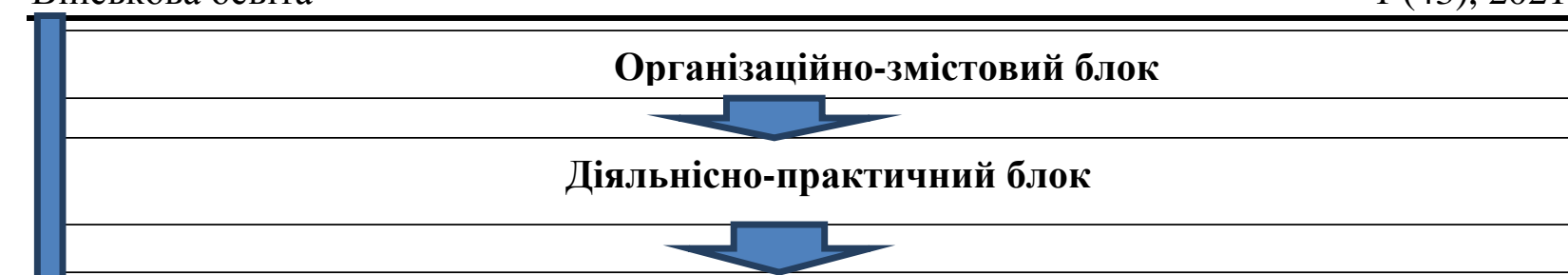

формування прикладної професійної компетентності: 1) мотиваційний, базовий; 2) розвивально-продуктивний; 3) діяльнісно-прогностичний

умови: розробити методику поетапного формування прикладних професійних компетентностей майбутніх офіцерів до дій в умовах радіаційної, хімічної та біологічної небезпеки із використанням засобів спеціальної фізичної підготовки в системі професійної освіти; внести зміни до змісту РПНД: «Бойове забезпечення» [29], «Спеціальна фізична підготовка» [30]; розробити прикладні функціональні комплекси які забезпечують розвиток та удосконалення спеціальної фізичної підготовленості майбутніх офіцерів, які забезпечують надійне та ефективне виконання ними завдань за призначенням у різних умовах службово-бойової діяльності (змодельованих умовах бойових дій); розробити апробувати та впровадити методики тестування рівня готовності майбутніх офіцерів до дій в умовах радіаційної, хімічної та біологічної небезпеки (умовах значного психофізичного навантаження).

Навчально-методичне забезпечення: навчально-методичний комплекс, який забезпечує вивчення курсантами навчальних дисциплін: «Бойове забезпечення» [29], «Спеціальна фізична підготовка» [30], навчальні посібники, методичні рекомендації та

Кадрове забезпечення: залучення до проведення практичних занять навчальних дисциплін: «Бойове забезпечення» «СФП», (форм фізичної підготовки, тренажів) провідних учених та практиків зазначених наукових напрямів, використання у навчальному процесі результатів досвіду бойових дій, тощо

Методи навчання: тренажі, робота в парах, робота у складі відділення, індивідуальна робота, навчального взводу (групи), комплексне оцінювання, біомеханічний аналіз, відеоаналіз

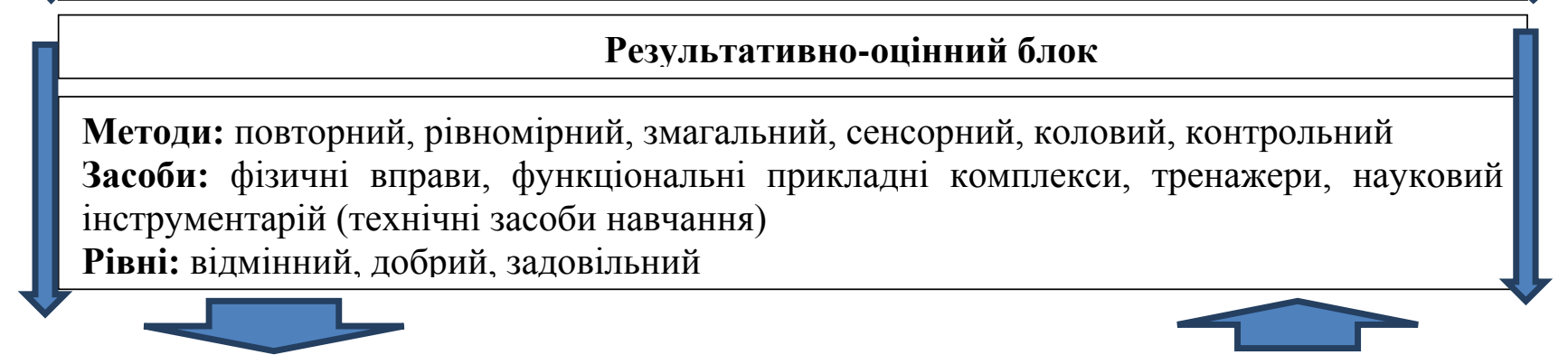

Авторська розробка: В. Шемчук, О. Хацаюк, В. Соколовський,

\section{Результат}

позитивна динаміка формування прикладних професійних компетентностей майбутніх офіцерів до дій в умовах радіаційної, хімічної та біологічної небезпеки (у різних умовах службово-бойової діяльності)

\section{А. Ковтуненко, Ю. Муштатов, О. Корнієнко}

Рис. 1. Змістово-функціональна модель формування прикладних професійних компетентностей курсантів НАНГУ до дій в умовах РХБН із акцентованим використанням засобів СФП 
Крім цього, у зміст супутного фізичного тренування курсантів ЕГ під час комплексних польових виходів, бойових стрільб (інших форм бойової та спеціальної підготовки, форм фізичної підготовки) включалися відповідні тренувальні завдання передбачені розробленим нами планом (табл. 1). Використання засобів спеціальної фізичної підготовки у поєднанні із елементами РХБЗ (та його засобами) сприяло стійкому формуванню прикладних професійних компетентностей майбутніх офіцерів (досліджуваних ЕГ), які необхідні для якісного виконання ними завдань за призначенням в умовах радіаційної, хімічної та біологічної небезпеки (результати порівняльного аналізу подано на рис. 2).

Дослідження ефективності сформованості прикладних професійних компетентностей у курсантів КГ та ЕГ здійснено у відповідності до діючої нормативної бази [18-20; 29-32], а також шляхом експертного оцінювання (визначено загальний рівень готовності досліджуваних КГ та ЕГ до дій в умовах радіаційної, хімічної та біологічної небезпеки) за 4-х бальною шкалою оцінювання, де «5»- максимальний бал, а «2» - мінімальний.

Відповідно до плану емпіричного дослідження, наприкінці педагогічного експерименту членами НДГ організовано практичну перевірку рівня готовності майбутніх офіцерів (курсантів КГ та ЕГ) до дій у змодельованих умовах радіаційної, хімічної та біологічної небезпеки. 3 цією метою нами було розроблено сценарій виконання навчально-бойового завдання в екстремальних умовах (РХБН) із досліджуваними курсантами КГ та ЕГ.

План контрольного випробування передбачав: здійснення марш кидку на 5 км із супутнім відпрацюванням тестових завдань передбачених нормативною базою з: бойової та спеціальної підготовки військовослужбовців НГУ [30] та фізичної підготовки військовослужбовців зазначеного вище інституції СБО із правоохоронними функціями [32], які мають найбільш інформативну значимість i демонструють рівень готовності (рівень сформованості прикладних професійних компетентностей) досліджуваних курсантів КГ та ЕГ (табл. 2).

Варто зауважити, що на всіх етапах проходження комплексного маршкидку на 5 км у змодельованих умовах радіаційної, хімічної та біологічної небезпеки (табл. 2) було організовано медичне забезпечення. Крім цього, досліджуваними курсантами КГ та ЕГ використовувалася штатна зброя (екіпіровка), індивідуальні засоби захисту необхідні для дій у зазначених вище умовах. Також на кожному етапі та на фініші здійснювалася перевірка озброєння та екіпіровки, за не дотримання встановлених вимог згідно умов виконання комплексного марш-кидку на 5 км нараховувалися штрафні секунди. 


\section{План}

впровадження в освітній процес досліджуваних курсантів ЕГ змістовофункціональної моделі формування прикладних професійних компетентностей необхідних для виконання завдань за призначенням в умовах радіаційної, хімічної та біологічної небезпеки із акцентованим використанням засобів СФП

\begin{tabular}{|c|c|c|}
\hline $\begin{array}{l}\text { № } \\
\text { 3/II }\end{array}$ & $\begin{array}{c}\text { Блоки педагогічного } \\
\text { експерименту }\end{array}$ & Зміст тренувальних завдань \\
\hline 1. & $\begin{array}{l}\text { перший } \\
\text { вересень- } \\
\text { листопад }(2019 \text { р.) }\end{array}$ & 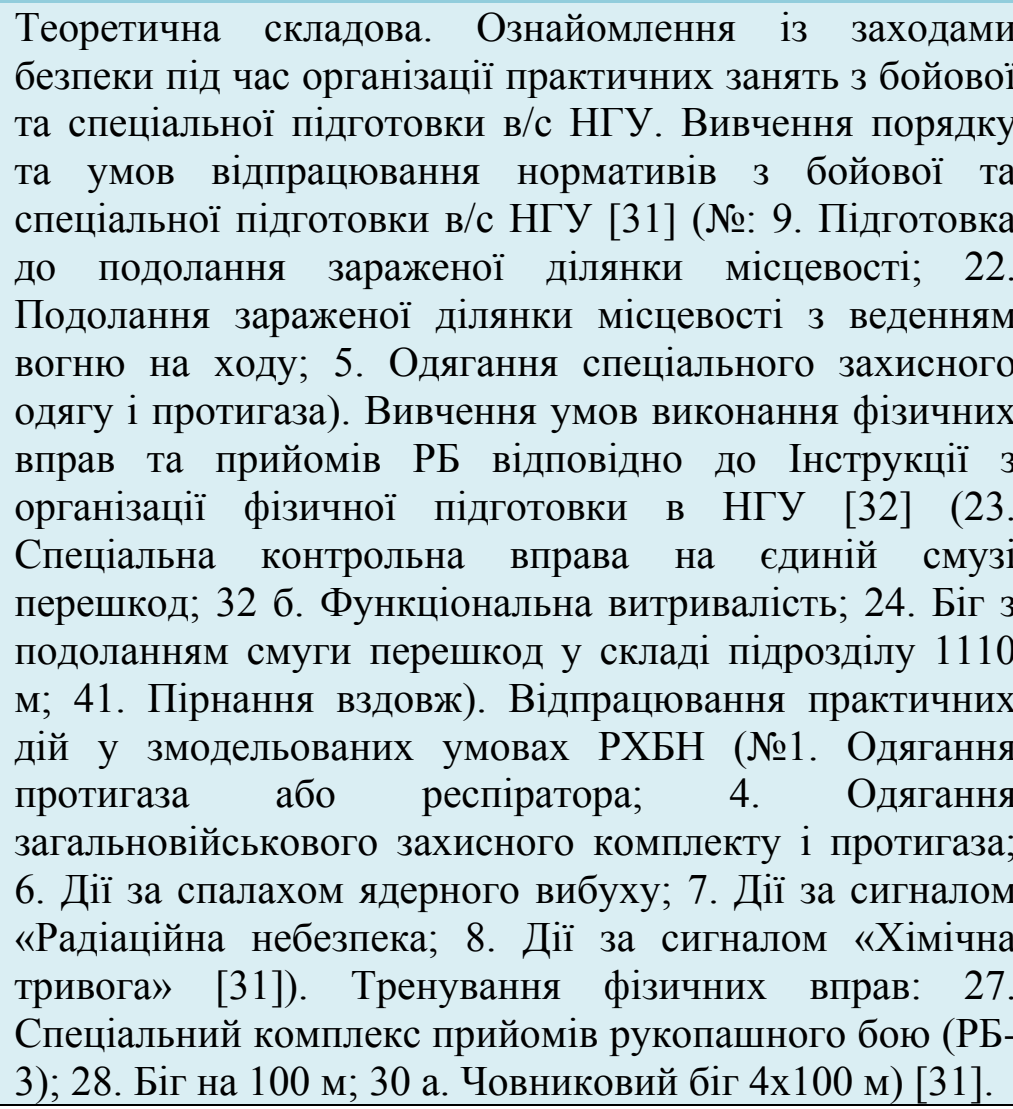 \\
\hline 2. & $\begin{array}{l}\text { другий } \\
\text { (грудень 2019- } \\
\text { лютий } 2020 \text { p.p.) }\end{array}$ & $\begin{array}{l}\text { Практичне відпрацювання нормативів } 3 \text { бойової та } \\
\text { спеціальної підготовки в/с НГУ [31] (№: 9. Підготовка } \\
\text { до подолання зараженої ділянки місцевості; } 22 . \\
\text { Подолання зараженої ділянки місцевості } 3 \text { веденням } \\
\text { вогню на ходу; 5. Одягання спеціального захисного } \\
\text { одягу і протигаза). Тренування фізичних вправ: 31. Біг } \\
\text { на } 1 \text { км; подолання окремих перешкод в протигазі; } 32 \text { б. } \\
\text { Функціональна витривалість; 33. Метання гранати Ф-1 } \\
\text { на дальність [32] (фізичні вправи виконувати } \\
\text { протигазі). }\end{array}$ \\
\hline 3. & $\begin{array}{l}\text { mретій } \\
\text { (березень- } \\
\text { травень } 2020 \text { р.) }\end{array}$ & 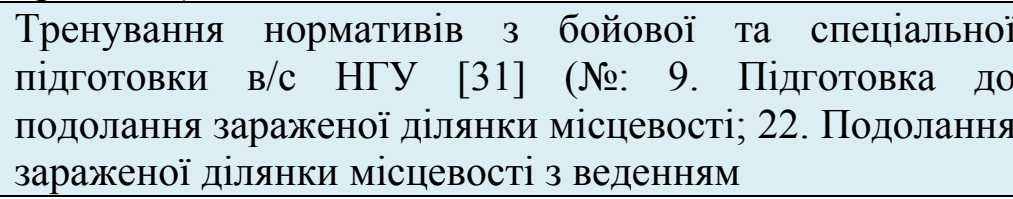 \\
\hline
\end{tabular}




\begin{tabular}{|c|c|c|}
\hline & & Продовження табличі 1 \\
\hline & & $\begin{array}{l}\text { вогню на ходу; 5. Одягання спеціального захисного } \\
\text { одягу і протигаза; 7. Дії за сигналом «Радіаційна } \\
\text { небезпека»; 8. Дії за сигналом «Хімічна тривога»). } \\
\text { Тренування фізичних вправ: } 32 \text { б. Функціональна } \\
\text { витривалість; 24. Біг з подоланням смуги перешкод у } \\
\text { складі підрозділу } 1110 \text { м; } 30 \text { а. Човниковий біг 4х100 м) } \\
\text { [32] (фізичні вправи виконувати в протигазі). }\end{array}$ \\
\hline 4. & $\begin{array}{l}\text { четвертий } \\
\text { (червень- } \\
\text { серпень } 2020 \text { р.) }\end{array}$ & $\begin{array}{l}\text { Відпрацювання практичних дій у змодельованих } \\
\text { умовах РХБН (№1. Одягання протигаза або } \\
\text { респіратора; 5. Одягання спеціального захисного одягу } \\
\text { i протигаза 7. Дії за сигналом «Радіаційна небезпека»; } \\
\text { №: 9. Підготовка до подолання зараженої ділянки } \\
\text { місцевості; 22. Подолання зараженої ділянки місцевості } \\
\text { зеденням вогню на ходу [31]). } \\
\text { Тренування фізичних вправ: 27. Спеціальний комплекс } \\
\text { прийомів рукопашного бою (РБ-3); } 30 \text { а. Човниковий } \\
\text { біг 4х100 м, 31. Біг на 1 км; 32 б. Функціональна } \\
\text { витривалість; подолання окремих перешкод в } \\
\text { протигазі; 33. Метання гранати Ф-1 на дальність [32] } \\
\text { (фізичні вправи виконувати в протигазі). }\end{array}$ \\
\hline 5. & $\begin{array}{l}\text { 'ятий } \\
\text { (вересень- } \\
\text { листопад } 2020 \text { р.) }\end{array}$ & $\begin{array}{l}\text { Відпрацювання практичних дій у змодельованих } \\
\text { умовах РХБН (№4. Одягання загальновійськового } \\
\text { захисного комплекту і протигаза; 6. Дії за спалахом } \\
\text { ядерного вибуху; 7. Дії за сигналом «Радіаційна } \\
\text { небезпека»; 22. Подолання зараженої ділянки } \\
\text { місцевості з веденням вогню на ходу [31]). } \\
\text { Тренування фізичних вправ: подолання окремих } \\
\text { перешкод в протигазі; 2. Підтягування на перекладині; } \\
\text { 27. Спеціальний комплекс прийомів рукопашного бою } \\
\text { (РБ-3); 31. Біг на 1 км; 32 б. Функціональна } \\
\text { витривалість; 33. Метання гранати Ф-1 на дальність } \\
\text { [32]; 34. Марш-кидок на } 5 \text { км [32] (фізичні вправи } \\
\text { виконувати в протигазі). }\end{array}$ \\
\hline 6. & $\begin{array}{l}\text { шостий } \\
\text { (грудень 2020-січень } \\
2021 \text { р.р.) }\end{array}$ & $\begin{array}{l}\text { Контрольна перевірка рівня сформованості прикладних } \\
\text { професійних компетентностей у курсантів КГ та ЕГ } \\
\text { необхідних для виконання завдань за призначенням в } \\
\text { умовах радіаційної, хімічної та біологічної небезпеки } \\
\text { (за умовами комплексного марш-кидка на } 5 \text { км). } \\
\text { Інтерпретація отриманих результатів педагогічного } \\
\text { експерименту. Складання звіту емпіричного } \\
\text { дослідження. Написання статті та тез доповідей за } \\
\text { результатами педагогічного експерименту. Визначення } \\
\text { подальших напрямів наукової розвідки у обраному } \\
\text { напрямі дослідження. }\end{array}$ \\
\hline
\end{tabular}

(примітка: РХБН - радіаџійна, хімічна та біологічна небезпека; РБ-3 - Спеиіальний комплекс прийомів рукопашного бою №3) 


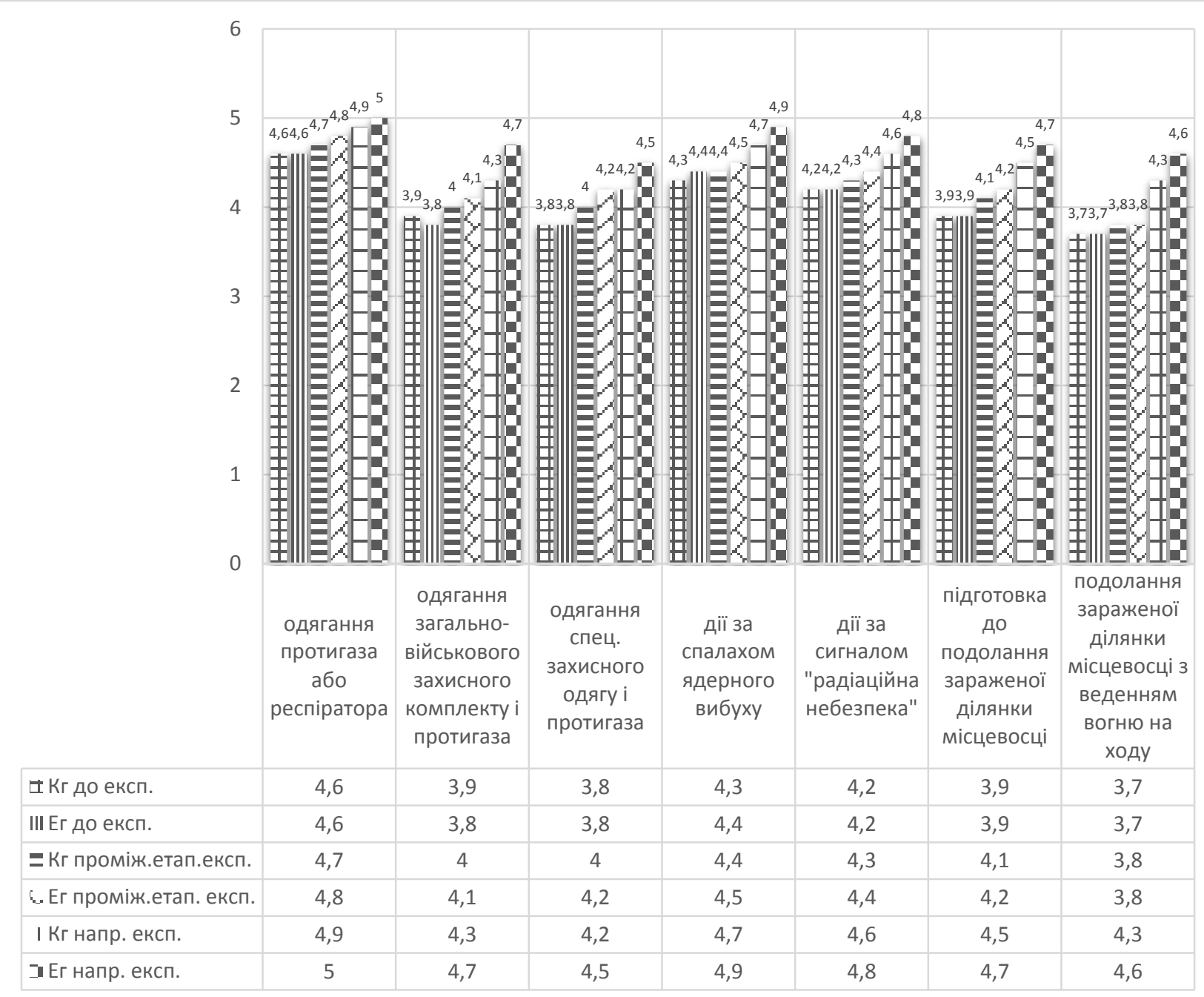

Рис. 2. Рівень сформованості прикладних професійних компетентностей курсантів НАНГУ до дій в умовах радіаційної, хімічної та біологічної небезпеки

Таким чином у відповідності до результатів комплексного марш-кидку на 5 км у змодельованих умовах радіаційної, хімічної та біологічної небезпеки (результати надано на рис. 3) нами встановлено, що у досліджуваних курсантів ЕГ рівень сформованості прикладних професійних компетентностей необхідних для виконання завдань за призначенням у зазначених вище умовах $€$ більш стійким та високим на відміну від досліджуваних курсантів КГ. Це підтверджують часові показники, а також результати відпрацювання контрольних завдань на етапах марш-кидку на 5 км. 
Таблиця 2

Послідовність проходження комплексного марш-кидку на 5 км у змодельованих умовах радіаційної, хімічної та біологічної небезпеки

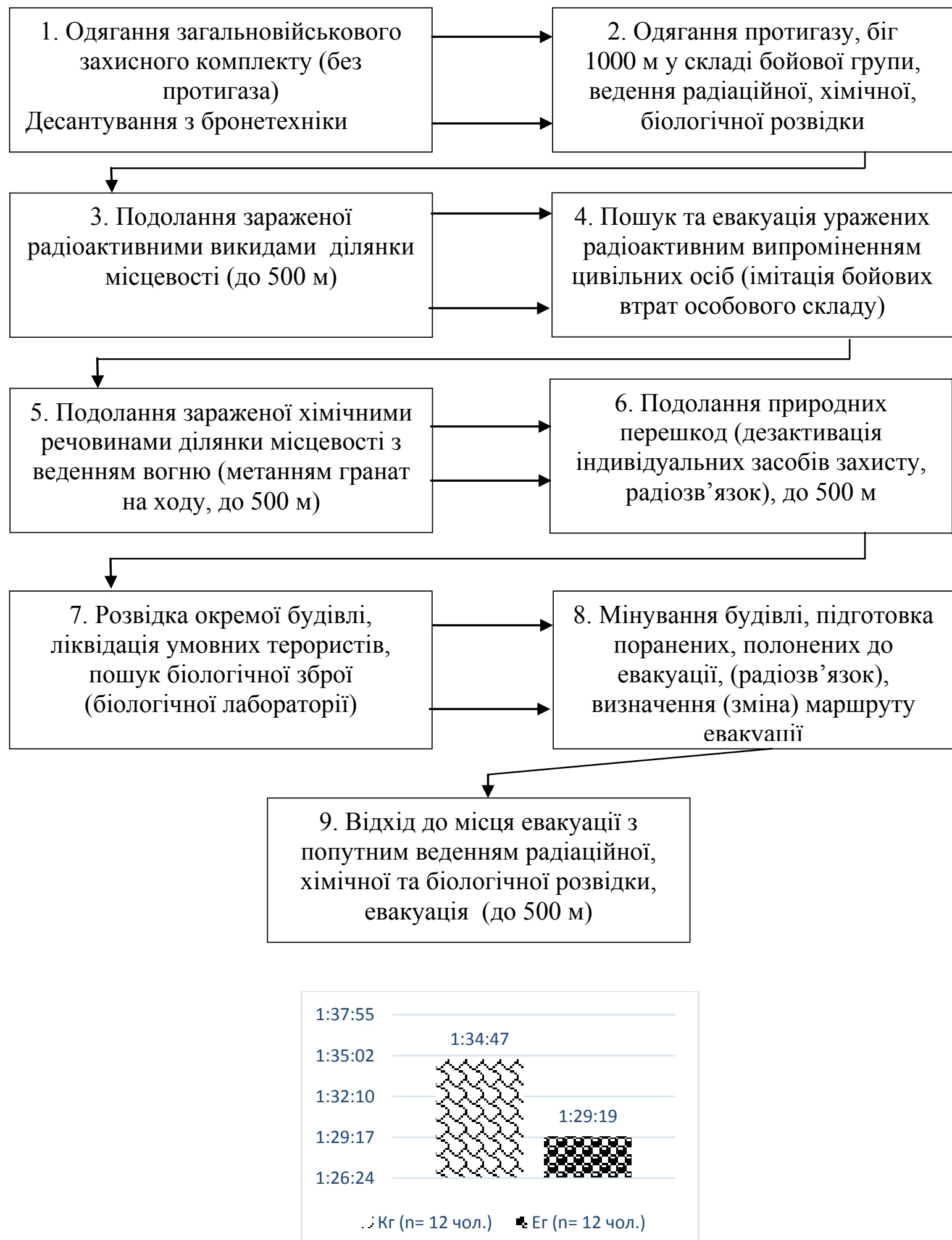

Рис. 3. Результати виконання комплексного марш-кидку на 5 км досліджуваними курсантами КГ та ЕГ у змодельованих умовах радіаційної, хімічної та біологічної небезпеки

При порівнянні показників до та після використання сконструйованої членами НДГ змістово-функціональної моделі (рис. 1) із акцентованим 
використанням засобів спеціальної фізичної підготовки (та плану іiі впровадження) встановлено, що результати, отримані наприкінці педагогічного експерименту у досліджуваних групах зросли відносно вихідних даних, i дані відмінності переважно є достовірні (ЕГ, $p \leq 0,05)$.

Висновки та перспективи подальших досліджень. Відповідно до результатів дослідження нами сконструйовано та апробовано змістовофункціональну модель формування професійних компетентностей майбутніх офіцерів (курсантів НАНГУ) до дій в умовах радіаційної, хімічної та біологічної небезпеки із акцентованим використанням засобів спеціальної фізичної підготовки. Враховуючи результати педагогічного експерименту можливо констатувати, що зазначена вище педагогічна модель (рис. 1) iз засобами спеціальної фізичної підготовки має позитивний вплив на формування прикладних професійних компетентностей у досліджуваних курсантів ЕГ, які у майбутній службово-бойовій діяльності забезпечать ефективне виконання завдань за призначенням, а також якісним чином організують систему професійної підготовки підлеглого особового складу.

Крім цього, наприкінці дослідження, членами науково-дослідної групи встановлено, що рівень витривалості, швидкості, сили та спритності у досліджуваних курсантів ЕГ підвищився, на відміну від курсантів КГ про що свідчать результати заліку 3 навчальної дисципліни «Спеціальна фізична підготовки» (7 семестр 2020/2021 навчальний рік, у досліджуваних ЕГ середній рівень спеціальної фізичної підготовленості складає 4,9 бали, у той час, як у курсантів КГ зазначений показник знаходиться в межах 4,6 бали). Варто зауважити, що також підвищилися якісні показники відпрацювання нормативів з бойової та спеціальної підготовки військовослужбовців НГУ, так у курсантів ЕГ середній бал за виконання тренувальних завдань складає 4,7 бали, у той час, як у курсантів КГ зазначений показник сягає відмітки 4,2 бали.

Членами науково-дослідної групи встановлено високу ефективність засобів спеціальної фізичної підготовки, що сприяло ефективному формуванню прикладних професійних компетентностей у досліджуваних курсантів ЕГ. Зазначена педагогічна модель може використовуватися в системі професійної освіти офіцерів інших інституцій сектору безпеки і оборони України із урахуванням нормативно-правової бази, що сприятиме більш стійкому та якісному формуванню прикладних професійних компетентностей, які необхідні для виконання завдань в умовах радіаційної, хімічної та біологічної небезпеки (екстремальних умовах).

Результати дослідження впроваджені в систему професійної освіти курсантів груп спеціального призначення командно-штабного факультету НАНГУ. Напрями подальших досліджень передбачають удосконалення спеціальної фізичної підготовленості майбутніх офіцерів НГУ до тривалих дій в умовах низьких температур (несприятливих кліматичних умов). 


\section{ЛІТЕРАТУРА}

1. Бойко О. Ціннісна концепція формування лідерської компетентності майбутніх офіцерів Збройних Сил України у ВВНЗ / О. Бойко. - К. : Військова освіта, 2017. № 2 (36). C. 7-18.

2. Боровик Л. Обгрунтування теоретичної моделі становлення та розвитку психолого-педагогічної компетентності майбутніх офіцерів-прикордонників / Л. Боровик. К. : Військова освіта, 2018. № 1 (37). - С. 37-47.

3. Хацаюк О. В. Педагогічна модель функціональної готовності курсантів НАНГУ до виконання завдань за призначенням / О. В. Хацаюк. - Слов'янськ : Взаємодія духовного й фізичного виховання в становленні гармонійно розвиненої особистості, 2019. Вип. 2. - С. 327-328.

4. Саморок M. Формування професійних компетентностей у правоохоронців МВС України підрозділів спеціального призначення до дій у гірських умовах / М. Саморок, B. Халеп, Н. Височіна, О. Хацаюк, Р. Іванішин. - Запоріжжя : Педагогіка формування творчої особистості у вищій і загальноосвітній школах, 2020. Вип. 71. Т. 2. - С. 208-216.

5. Шемчук $B$. А. Використання технічних засобів навчання на початковому етапі формування навичок рукопашного бою майбутніх офіцерів / В. А. Шемчук, А. В. Турчинов, $B$. Б. Климович, С. I. Гончаров, Р. М. Тріщун. - Запоріжжя : Педагогіка формування творчої особистості у вищій і загальноосвітній школах, 2020. Вип. 70. Т. 4. - С. 217-222.

6. Шемчук B. A. Педагогічна модель удосконалення спеціальної фізичної підготовленості майбутніх офіцерів засобами службово-прикладних єдиноборств / В. А. Шемчук, Н. Б Вербин, О. С. Нестеров, М. М. Василенко, С. В. Малахов. - Запоріжжя : Педагогіка формування творчої особистості у вищій і загальноосвітній школах, 2020. Вип. 71. T. 2. - C. 241-248.

7. Войтех О. Принципи та підходи до підготовки національного персоналу Збройних Сил України до участі у міжнародних операціях з підтримання миру і безпеки / О. Войтех. - К. : Військова освіта, 2019. № 1 (39). - С. 93-101.

8. Флорін О. П. Обгрунтування структури та функцій системи бойової підготовки Національної гвардії України / О. П. Флорін, С. О. Стародубцев, О. М. Шаповал. - Харків : Честь і закон, 2015. № 4 (55). - С. 44-53.

9. Приходько I. I. Психологічні особливості службово-бойової діяльності військовослужбовців Національної гвардії України при проведенні антитерористичної операції / І. І. Приходько. - Харків : Військово-спеціальні науки, 2015. Вип. 2. - С. 35-39.

10. Хацаюк О. В. Модель формування готовності майбутніх офіцерівправоохоронців до застосування заходів фізичного впливу в різних умовах службовооперативної діяльності / О. В. Хацаюк, О. С. Єлісєєва, В. Л. Жуков, В. П. Клименко, Ю. М. Бережний. - Одеса : Інноваційна педагогіка, 2020. Т. 2 (29). - С. 174-178.

11. І Ісмаілов І. Основи організації і застосування підрозділів військ РХБ захисту ЗС України під час ліквідації НС НА ПНО / І. Ісмаілов, А. Ісмаілов. - К. : Науковий збірник ІДУЦЗ, 2015. № 3. - С. 67-71.

12. Трегубенко С. Аналіз організації та здійснення радіаційного, хімічного, біологічного захисту підрозділу (частини) у сучасних бойових діях / С. С. Трегубенко, О. А. Гутченко, I. М. Тіхонов. - Харків : Системи озброєння і військова техніка, 2015. № 2 (42). - C. 176-179.

13. Лазебник С. В. Моделі та методика формування раціональної структури системи радіаційного, хімічного, біологічного захисту повітряного командування / С. В. Лазебник, С. І. Поплавець. - Харків : Системи озброєння і військова техніка, 2019. № 3 (59). - C. 43-47.

14. Кузьменко Л. Ф. Методика оцінки ефективності системи РХБ захисту та обгрунтування рекомендацій : автореф. дис. ... канд. військ. наук : 20.01.01 / Кузьменко Леонід Федорович. - К., 2004. - 23 с. 
15. Лещенко О. Я. Трансформація системи цивільного захисту України в умовах сучасних воєнно-політичних конфліктів гібридного типу : дис. ... канд. політ. наук : 21.01.01 / Олександр Якович Лещенко. - К., 2020. - 293 с.

16. Иващенко О. Ю. Анализ факторов, влияющих на эффективность функционирования системы защиты личного состава от поражающих факторов ядерного, химического и биологического оружия / О. Ю. Иващенко. - Уфа : Технический журнал «Наука XXI века», 2017. № 7. - С. 120-129.

17. Системи екологічного керування. Вимоги та настанови щодо застосування : ДСТУ ISO 14001:2006. - Київ : Держспоживстандарт України, 2006. - 20 с.

18. Шаталов О. С. Силабус навчальної дисиипліни «Захист у надзвичайних ситуаціях» для здобувачів вищої освіти ступеня "бакалавр», які навчаються за освітньопрофесійною програмою «Охорона праџі» спечіальності 263 «Цивільна безпека» : силабус. Рівне : НУВГП, 2020. - 18 с.

19. Нормативи з бойової та спеціальної підготовки військових частин (підрозділів) Національної гвардії України : нормативи. - Київ : ГУ НГУ, 2016. - 12 с.

20. Технічне переоснащення підрозділів РХБ захисту сучасними зразками ОВТ : бюлетень. - К. : Бюлетень 3 воєнно-економічних та воєнно-технічних питань іноземних держав, 2006. № 2 (72). -62 с.

21. Панченко В. Ю. Способи ізоляції дій підрозділів внутрішніх військ та їх класифікація / В. Ю. Панченко, С. Г. Башкатов, Т. А. Сутюшев, П. В. Пістряк. - Харків : Збірник наукових праць ХУПС, 2013. № 2 (35). - С. 202-213.

22. Кириченко О. В. Законодавче регулювання протидії злочинам, пов'язаним 3 небезпечними хімічними, біологічними, радіоактивними та ядерними матеріалами в Україні / О. В. Кириченко. - Дніпро : Міжнародна та національна безпека: теоретичні і прикладні аспекти, 2020. № 4. - С. 277-280.

23. Моргунов О. А. Напрями розвитку військово-прикладних навичок застосування засобів індивідуального захисту та активної оборони курсантамиправоохоронцями / О. А. Моргунов, О. А. Ярещенко О. В., Хацаюк. - Харків : Честь і закон, 2017. № 4 (63). - С. 49-55.

24. Максимчук Б. А. Формування військово-прикладних навичок рукопашного бою у майбутніх офіцерів Національної гвардії України груп спеціального призначення / Б. А. Максимчук, Є. О. Терехов, О. В. Хацаюк. - Wien : NGO «Europäische Wissenschaftsplattform», 2019. № 3. - C. 98-100.

25. Войтех О. Фахова компетентність офіцерів національного персоналу Збройних Сил України / О. Войтех, К. Войтех. - Київ : Військова освіта, 2020. № 1 (41). - С. 70-81.

26. Горбачевський С. Інформаційна система оцінки професійних компетентностей офіцерів - випускників вищих військових навчальних закладів тактичного рівня / С. Горбачевський. - Київ : Військова освіта, 2020. № 2 (42). - С. 120-129.

27. Konokh A. Use of Symbiosis of innovative-traditional methods of teaching special disciplines / A. Konokh, V. Shemchuk, O. Konokh, I. Budz, I. Buzhyna. - India : Journal of Critical Reviews, 2020. № 7 (13). - C. 113-115.

28. Шемчук $B$. Модель формування професійних компетентностей майбутніх офіцерів - фахівців фізичної підготовки і спорту / В. Шемчук, В. Поливанюк, Ю. Муштатов, О. Федоренко, А. Одеров. - Дрогобич : Актуальні питання гуманітарних наук ДДПУ ім. І.Франка, 2020. Вип. 29. Т. 4. - С. 240-248.

29. Робоча програма навчальної дисципліни «Бойове забезпечення» : РПНД. Харків : НАНГУ, 2018. - 38 с.

30. Робоча програма навчальної дисципліни «Спеціальна фізична підготовка» : РПНД. - Харків : НАНГУ, 2018. - 44 с.

31. Нормативи з бойової та спеціальної підготовки військових частин (підрозділів) Національної гвардії України (наказ КНГУ від 14.03.2016 №151) : нормативи. - К. : ГУ НГУ, 2016. -12 c. 
32. Інструкція з організації фізичної підготовки в Національної гвардії України (наказ МВСУ від 13.10.2014 №1067) : інструкція. - К. : ГУ НГУ, 2019. - 146 с.

\section{REFERENCES}

1. Boiko, O. (2017). Tsinnisna kontseptsiia formuvannia liderskoi kompetentnosti maibutnikh ofitseriv Zbroinykh Syl Ukrainy u VVNZ [Value concept of formation of leadership competence of future officers of the Armed Forces of Ukraine in the Higher Military Educational Institution]. Viiskova osvita, № 2 (36), 7-18.

2. Borovyk, L. (2018). Obhruntuvannia teoretychnoi modeli stanovlennia ta rozvytku psykholoho-pedahohichnoi kompetentnosti maibutnikh ofitseriv-prykordonnykiv [Substantiation of the theoretical model of formation and development of psychological and pedagogical competence of future border guards]. Viiskova osvita, № 1 (37), 37-47.

3. Khatsaiuk, O. V. (2019). Pedahohichna model funktsionalnoi hotovnosti kursantiv NANHU do vykonannia zavdan za pryznachenniam [Pedagogical model of functional readiness of NANGU cadets to perform tasks by appointment]. Vzaiemodiia dukhovnoho y fizychnoho vykhovannia v stanovlenni harmoniino rozvynenoi osobystosti, Vyp. 2, 327-328.

4. Samorok, M., Khalep, V., Vysochina, N., Khatsaiuk, O., Ivanishyn R. (2019). Formuvannia profesiinykh kompetentnostei $\mathrm{u}$ pravookhorontsiv MVS Ukrainy pidrozdiliv spetsialnoho pryznachennia do dii u hirskykh umovakh [Formation of professional competencies of law enforcement officers of the Ministry of Internal Affairs of Ukraine of special purpose units for actions in mountain conditions]. Pedahohika formuvannia tvorchoi osobystosti $u$ vyshchii i zahalnoosvitnii shkolakh, Vyp. 71. T. 2., 208-216.

5. Shemchuk, V. A., Turchynov, A. V., Klymovych, V. B., Honcharov, Ye. I., Trishchun, R. M. (2020). Vykorystannia tekhnichnykh zasobiv navchannia na pochatkovomu etapi formuvannia navychok rukopashnoho boiu maibutnikh ofitseriv [The use of technical means of training at the initial stage of formation of hand-to-hand combat skills of future officers]. Pedahohika formuvannia tvorchoi osobystosti u vyshchii i zahalnoosvitnii shkolakh, Vyp. 70. T. 4., 217-222.

6. Shemchuk, V. A., N. B Verbyn, O. S. Nesterov, M. M. Vasylenko, Ye. V. Malakhov. (2020). Pedahohichna model udoskonalennia spetsialnoi fizychnoi pidhotovlenosti maibutnikh ofitseriv zasobamy sluzhbovo-prykladnykh yedynoborstv [Pedagogical model of improvement of special physical training of future officers by means of service-applied martial arts]. Pedahohika formuvannia tvorchoi osobystosti u vyshchii i zahalnoosvitnii shkolakh, Vyp. 71. T. 2., 241-248.

7. Voitekh, O. (2019). Pryntsypy ta pidkhody do pidhotovky natsionalnoho personalu Zbroinykh Syl Ukrainy do uchasti u mizhnarodnykh operatsiiakh z pidtrymannia myru i bezpeky [Principles and approaches to training national personnel of the Armed Forces of Ukraine to participate in international peacekeeping and security operations]. Viiskova osvita, № 1 (39), 93101.

8. Florin, O. P., Starodubtsev, S. O. Shapoval, O. M. (2015). Obhruntuvannia struktury ta funktsii systemy boiovoi pidhotovky Natsionalnoi hvardii Ukrainy [Substantiation of the structure and functions of the combat training system of the National Guard of Ukraine]. Chest $\mathrm{i}$ zakon, № 4 (55), 44-53.

9. Prykhodko, I. I. (2015). Psykholohichni osoblyvosti sluzhbovo-boiovoi diialnosti viiskovosluzhbovtsiv Natsionalnoi hvardii Ukrainy pry provedenni antyterorystychnoi operatsii [Psychological features of service and combat activity of servicemen of the National Guard of Ukraine during anti-terrorist operation]. Viiskovo-spetsialni nauky, Vyp. 2., 35-39.

10. Khatsaiuk, O. V., Yelisieieva, O. S., Zhukov, V. L., Klymenko, V. P., Berezhnyi, Yu. M. (2020). Model formuvannia hotovnosti maibutnikh ofitseriv-pravookhorontsiv do zastosuvannia zakhodiv fizychnoho vplyvu v riznykh umovakh sluzhbovo-operatyvnoi diialnosti [Model of formation of readiness of future law enforcement officers to apply measures of physical influence in various conditions of service and operational activity]. Innovatsiina pedahohika, T. 2 (29), 174-178. 
11. Ismailov, I., Ismailov, A. (2015). Osnovy orhanizatsii i zastosuvannia pidrozdiliv viisk RKhB zakhystu ZS Ukrainy pid chas likvidatsii NS NA PNO [Fundamentals of the organization and application of units of the RHB troops of the Armed Forces of Ukraine during the liquidation of the Emergency Situations on the PNO]. Naukovyi zbirnyk IDUTsZ, № 3, 67-71.

12. Trehubenko, S. S., Hutchenko, O. A., Tikhonov, I. M. (2015). Analiz orhanizatsii ta zdiisnennia radiatsiinoho, khimichnoho, biolohichnoho zakhystu pidrozdilu (chastyny) u suchasnykh boiovykh diiakh [Analysis of the organization and implementation of radiation, chemical, biological protection of the unit (unit) in modern hostilities]. Systemy ozbroiennia i viiskova tekhnika, № 2 (42), 176-179.

13. Lazebnyk, S. V., Poplavets, S. I. (2019). Modeli ta metodyka formuvannia ratsionalnoi struktury systemy radiatsiinoho, khimichnoho, biolohichnoho zakhystu povitrianoho komanduvannia [Models and methods of forming a rational structure of the system of radiation, chemical, biological protection of air command]. Systemy ozbroiennia i viiskova tekhnika, № 3 (59), 43-47.

14. Kuzmenko, L. F. (2004). Metodyka otsinky efektyvnosti systemy RKhB zakhystu ta obgruntuvannia rekomendatsii [Methods for assessing the effectiveness of the RHB protection system and substantiation of recommendations]. (Abstract of $\mathrm{PhD}$ thesis), Kyiv.

15. Leshchenko, O. Ya. (2020). Transformatsiia systemy tsyvilnoho zakhystu Ukrainy v umovakh suchasnykh voienno-politychnykh konfliktiv hibrydnoho typu [Transformation of the civil defense system of Ukraine in the conditions of modern military-political conflicts of hybrid type]. (Abstract of $\mathrm{PhD}$ thesis), Kyiv.

16. Yvashchenko, O. Yu. (2017). Analyz faktorov, vlyiaiushchykh na эffektyvnost funktsyonyrovanyia systemu zashchytu lychnoho sostava ot porazhaiushchykh faktorov yadernoho, khymycheskoho y byolohycheskoho oruzhyia [Analysis of the factors influencing the effectiveness of the personnel protection system against the damaging factors of nuclear, chemical and biological weapons]. Tekhnycheskyi zhurnal «Nauka XXI veka», № 7, 120-129.

17. DSTU ISO 14001:2006. (2006). Systemy ekolohichnoho keruvannia. Vymohy ta nastanovy shchodo zastosuvannia [Environmental management systems. Requirements and guidelines for use]. Derzhspozhyvstandart Ukrainy, 20.

18. Shatalov O. S. (2020). Sylabus navchalnoi dystsypliny «Zakhyst u nadzvychainykh sytuatsiiakh» dlia zdobuvachiv vyshchoi osvity stupenia «bakalavr», yaki navchaiutsia za osvitnoprofesiinoiu prohramoiu «Okhorona pratsi» spetsialnosti 263 «Tsyvilna bezpeka» [Syllabus of the discipline "Protection in Emergencies" for applicants for higher education degree "Bachelor" who study in the educational-professional program "Occupational Safety" specialty 263 "Civil Security"]. Syllabus, 18.

19. Nakaz KNHU vid 14.03.2016 № 151 (2016). Normatyvy z boiovoi ta spetsialnoi pidhotovky viiskovykh chastyn (pidrozdiliv) Natsionalnoi hvardii Ukrainy [Standards for combat and special training of military units (subdivisions) of the National Guard of Ukraine]. Normatyvy, 12.

20. Biuleten $\mathrm{z}$ voienno-ekonomichnykh ta voienno-tekhnichnykh pytan inozemnykh derzhav № 2 (72). (2006). Tekhnichne pereosnashchennia pidrozdiliv RKhB zakhystu suchasnymy zrazkamy OVT [Technical re-equipment of RHB protection units with modern samples of weapons]. Biuleten, 62.

21. Panchenko, V. Yu., Bashkatov, Ye. H., Sutiushev, T. A., Pistriak P. V. (2013). Sposoby izoliatsii dii pidrozdiliv vnutrishnikh viisk ta yikh klasyfikatsiia [Methods of isolating the actions of units of internal troops and their classification]. Zbirnyk naukovykh prats KhUPS, № 2 (35), 202-213.

22. Kyrychenko, O. V. (2020). Zakonodavche rehuliuvannia protydii zlochynam, poviazanym $\mathrm{z}$ nebezpechnymy khimichnymy, biolohichnymy, radioaktyvnymy ta yadernymy materialamy v Ukraini [Legislative regulation of combating crimes related to hazardous chemical, biological, radioactive and nuclear materials in Ukraine]. Mizhnarodna ta natsionalna bezpeka: teoretychni i prykladni aspekty, № 4, 277-280. 
23. Morhunov, O. A., Yareshchenko, O. A., Khatsaiuk, O. V. (2017). Napriamy rozvytku viiskovo-prykladnykh navychok zastosuvannia zasobiv indyvidualnoho zakhystu ta aktyvnoi oborony kursantamy-pravookhorontsiamy [Directions of development of military-applied skills of application of means of individual protection and active defense by cadets-militiamen]. Chest i zakon, № 4 (63), 49-55.

24. Maksymchuk, B. A., Terekhov, Ye. O., Khatsaiuk, O. V. (2019). Formuvannia viiskovo-prykladnykh navychok rukopashnoho boiu u maibutnikh ofitseriv Natsionalnoi hvardii Ukrainy hrup spetsialnoho pryznachennia [Formation of military-applied skills of hand-to-hand combat in future officers of the National Guard of Ukraine of special purpose groups]. NGO «Europäische Wissenschaftsplattform», № 3, 98-100.

25. Voitekh, O., Voitekh, K. (2020). Fakhova kompetentnist ofitseriv natsionalnoho personalu Zbroinykh Syl Ukrainy [Professional competence of officers of the national staff of the Armed Forces of Ukraine]. Viiskova osvita, № 4 (41), 70-81.

26. Gorbachevsky, S. (2020). Informatsiina systema otsinky profesiinykh kompetentnostei ofitseriv - vypusknykiv vyshchykh viiskovykh navchalnykh zakladiv taktychnoho rivnia [Information system for assessing the professional competencies of officers - graduates of higher military educational institutions of the tactical level]. Viiskova osvita, № 2 (42), 120-129.

27. Konokh A. Use of Symbiosis of innovative-traditional methods of teaching special disciplines / A. Konokh, V. Shemchuk, O. Konokh, I. Budz, I. Buzhyna. - India : Journal of Critical Reviews, 2020. № 7 (13). - P. 113-115.

28. Shemchuk, V. Model formuvannia profesiinykh kompetentnostei maibutnikh ofitseriv-fakhivtsiv fizychnoi pidhotovky i sportu / V. Shemchuk, V. Polyvaniuk, Yu. Mushtatov O. Fedorenko, A. Oderov. - Drohobych : Aktualni pytannia humanitarnykh nauk DDPU im. I. Franka, 2020. № 29. T. 4. - S. 240-248.

29. Ovcharenko, V. V. (2018). Robocha prohrama navchalnoi dystsypliny «Boiove zabezpechennia» [Working program of the discipline "Combat Support"]. RPND, 38.

30. Khatsaiuk, O. V. (2018). Robocha prohrama navchalnoi dystsypliny TsPP 14 «Spetsialna fizychna pidhotovka» (25 Voienni nauky, natsionalna bezpeka, bezpeka derzhavnoho kordonu) [Work program of the discipline CPP 14 "Special physical training" (25 Military sciences, national security, state border security)]. RPND, 44.

31. Poltorak, S. T. (2016). Normatyvy z boiovoi ta spetsialnoi pidhotovky viiskovykh chastyn (pidrozdiliv) Natsionalnoi hvardii Ukrainy (nakaz KNHU vid 14.03.2016 №151) [Standards for combat and special training of military units (divisions) of the National Guard of Ukraine (order of KNGU from 14.03.2016 №151)]. Normatyvy, 12.

32. Leshchenia, S. V., Orlenko, I. P., Meleshko, A. O., Zabrodskyi, S. S. (2019). Instruktsiia $\mathrm{z}$ orhanizatsii fizychnoi pidhotovky $\mathrm{v}$ Natsionalnii hvardii Ukrainy [Instruction on the organization of physical training in the National Guard of Ukraine]. Instruktsiia, 146.

\section{Резюме}

Вадим Шемчук, кандидат педагогических наук, Национальный университет обороны Украины имени Ивана Черняховского

Александр Хацаюк магистр, заслуженный тренер Украины, Харьковский национальный университет внутренних дел

Владимир Соколовский, кандидат педагогических наук, Национальная академия Национальной гвардии Украины 
Национальный университет обороны Украины имени Ивана Черняховского Юрий Муштатов, Национальный университет обороны Украины имени Ивана Черняховского

\section{Формирование профессиональных компетенций будущих офицеров к действиям в условиях радиационной, химической и биологической опасности}

Рассмотрена актуальная проблема формирования прикладных профессиональных компетенций будущих офищеров (на примере курсантов групп специального назначения Национальной академии Наџиональной гвардии Украины) $\kappa$ действиям в условиях радиационной, химической и биологической опасности. Подводя итоги мониторинга научнометодической и спечиальной литературь (интернет-ресурсов), членами научноисследовательской группь сконструировано $u$ апробировано содержательнофункииональная модель, которая обеспечивает формирование готовности будущих офицеров (курсантов групп специального назначения Национальной академии Наџиональной гвардии Украины) к действиям в экстремальных условиях (радиачионной, химической $u$ биологической опасности) с использованием средств специальной физической подготовки.

Согласно результатам эмпирического исследования, членами научноисследовательской группь установлено, что результаты, полученные в конце педагогического эксперимента в исследуемых группах, выросли относительно исходных данных, и эти различия преимущественно есть достоверные (EГ, $p \leq 0,05)$. Кроме этого, $в$ конце исследования, членами научно-исследовательской группы установлено, что уровень выносливости, скорости, силь и ловкости в исследуемых курсантов ЕГ повысился, в отличие от курсантов КГ о чем свидетельствуют результаты зачета по учебной дисциплине «Спечиальная физическая подготовки» (7 семестр 2020 / 2021 учебный год, в исследуемых ЕГ - средний уровень специальной физической подготовленности составляет 4,9 балла, в то время, как у курсантов КГ указанный показатель находится в пределах 4,6 балла). Стоит заметить, что также повысились качественные показатели отработки нормативов по боевой и спещииальной подготовки военнослужащих НГУ, так у курсантов ЕГ средний балл за выполнение тренировочных заданий составляет 4,7 балла, в то время, как у курсантов КГ указанный показатель достигает отметки 4,2 балла.

Членами научно-исследовательской группы установлена высокая эффективность средств специальной физической подготовки, что способствовало качественному формированию прикладных профессиональных компетениий у исследуемых курсантов ЕГ. Указанная педагогическая модель может использоваться в системе профессионального образования офииеров других институичий сектора безопасности $і$ оборонь Украиньл (с учетом их определенной нормативно-правовой базы), что обеспечит устойчивому $u$ качественному формированию прикладных профессиональных компетенций, которые необходимы для выполнения задач в условиях радиаџионной, химической и биологической опасности (экстремальных условиях).

Ключевые слова: биологическая защита, компетентностный подход, курсанты, радиачионная защита, педагогическая модель, профессиональное образование, профессиональная подготовка, специальная физическая подготовка, химическая защита

\section{SUMMARY}

Vadym Shemchuk, candidate of pedagogical sciences, The National Defence University of Ukraine named after Ivan Cherniakhovskyi Oleksandr Khatsaiuk master, Honored coach of Ukraine Kharkiv National University of Internal Affairs Volodymyr Sokolovsky, candidate of pedagogical sciences, 
National Academy of the National Guard of Ukraine

Artem Kovtunenko,

National Academy of the National Guard of Ukraine

Olexandr Kornienko,

The National Defence University of Ukraine named after Ivan Cherniakhovskyi

Yurii Mushtatov,

The National Defence University of Ukraine named after Ivan Cherniakhovskyi

\section{Formation of Professional Competencies of Future Officers to act in conditions of radiation, chemical and biological danger}

Introduction. The topical problem of formation of applied professional competencies of future officers (on the example of cadets of special purpose groups of the National Academy of the National Guard of Ukraine) to act in conditions of radiation, chemical and biological danger is considered. Summarizing the results of monitoring of scientific-methodical and special literature (Internet resources), members of the research group constructed and tested the content-functional model, which ensures the formation of readiness of future officers (cadets of special purpose groups of the National Academy of National Guard of Ukraine) to act in extreme conditions. (radiation, chemical and biological hazards) with the use of special physical training.

Purpose. The purpose of the study is to development and approbation of the pedagogical model of formation of applied professional competencies of future officers to actions in the conditions of radiation, chemical and biological danger with accentuated use of means of special physical training.

Methods. Analytical review and analysis of the results of scientific and methodological, special literature (Internet resources), pedagogical modeling, pedagogical observation, expert evaluation, methods of statistical processing of results, biomechanical analysis, video analysis, own experience of participation in hostilities (radiation, chemical and biological hazards) ), etc.

Results. When comparing the indicators before and after the use of the content-functional model constructed by the NDG members (Fig. 1) with the accentuated use of special physical training (and the plan of its implementation) it was found that the results obtained at the end of the pedagogical experiment in the studied groups increased relative to baseline. these differences are mostly significant ( $E G, p \leq 0.05$ ).

Originality. The members of the research group established the high efficiency of the means of special physical training, which contributed to the effective formation of applied professional competencies in the studied cadets EG. This pedagogical model can be used in the system of professional education of officers of other law enforcement agencies and special services of Ukraine, considering the legal framework, which will contribute to a more sustainable and highquality formation of applied professional competencies needed to perform tasks in radiation, chemical and biological hazards (extremal conditions). The results of the research are introduced into the system of professional education of cadets of special purpose groups of the command and staff faculty of NANGU. Areas of further research include improving the special physical readiness of future NGU officers for long-term operations in low temperatures (adverse climatic conditions).

Conclusion. According to the results of the research we have constructed and tested the content-functional model of formation of professional competencies of future officers (cadets of $N A N G U)$ to act in conditions of radiation, chemical and biological danger with accentuated use of special physical training. Given the results of the pedagogical experiment, it can be stated that the above pedagogical model (Fig. 1) with special physical training has a positive impact on the formation of applied professional competencies in the studied cadets EG, which in the future service-combat activity will provide effective performance of tasks on purpose, and also qualitatively organize system of professional training of the subordinated personnel. In addition, at the end of the study, members of the research group found that the level of endurance, speed, strength and agility in the studied cadets EG increased, in contrast to cadets KG as evidenced by 
the results of the test "Special Physical Training" (7 semester 2020/2021 academic year, in the studied EG - the average level of special physical fitness is 4.9 points, while the cadets KG this figure is within 4.6 points). It is worth noting that the quality of the standards for combat and special training of NGU servicemen has also increased, so the average score for cadets Eg for training tasks is 4.7 points, while for cadets $K G$ this figure reaches 4.2 points.

Keywords: biological protection, competence approach, cadets, radiation protection, pedagogical model, professional education, professional training, special physical training, chemical protection. 